\title{
Väärentäjän tila kirjallisuudessa
}

\section{Sanna Nyqvist \& Outi Oja: Kirjalliset väärennökset: Huijauksia, plagiaatteja ja luovia lainauksia. Helsinki: Gaudeamus, 2018, 381 s.}

Mikä luo kirjallisuudessa omanlaisensa tilan väärentäjän, huijarin, plagiaattorin tai luovan lainaajan toiminnalle? Uudessa kirjassaan Kirjalliset väärennökset: Huijauksia, plagiaatteja ja luovia lainauksia Sanna Nyqvist ja Outi Oja perustelevat hyvin metodinsa:

Kuvataiteessa voi ansaita omaisuuksia väärentämällä mestareita ja musiikissa tekemällä hittibiisin, jota muut eivät malta olla kopioimatta. Kirjallisuuden väärentäminen ei sen sijaan tee rikkaaksi. Kirjallisuus eroaakin sisartaiteista siinä, miten moninaisia motiiveja väärentämiseen löytyy ja miten monin eri tavoin plagiaatteja kirjallisuuskeskusteluissa puidaan. Siksi kirjallisuuden väärennöksiä ja niiden reunaehtoja on tarpeen käsitellä omana ilmiönään. (11)

On hyvä tuntea sekä kirjallisuutta yleensä että kirjallisia väärennöksiä erikseen; näin meille avautuu mahdollisuus oppia tuntemaan ihmistä paremmin kuin esimerkiksi keskittymällä vaikkapa kuvataiteeseen tai musiikkiin.

Friedrich Nietzschen mukaan totuus on vain (yksi) valheen aspekti. Gresistinä ja latinistina hän kävisi hyvästä postmodernistista jo ennen tuon idean löytämistä tietään jumalaisten ideoiden joukkoon. Suomessa onkin pitkälti toteutunut Nietzschen ohje, ettei Jumalaa saada länsimaissa pois päiviltä, ellei ensin vapauduta normatiivisesta grammatiikasta (so. kieliopista ja kirjallisuudesta). Hyvin voi tuskin edes tuo Jumala, jonka ihminen loi kuvakseen. Tämä"anything goes" -ajattelu tekee monenmoisesta "vilungista" rahallisesti tai muuten tuottoisaa - toisin kuin todesta, totuudesta, hyvästä ja kauniista (jotka kaikki edustavat jo vanhanaikaiseksi käynyttä platonismia ja yhtä epäilyttävää absoluuttista moraalikonseptia).

Sofisti Protagoras sanoi kaiken olevan totta ja kaikkien olevan oikeassa. Meidän on syytä katsoa, että Protagoras on toistaiseksi nujertanut Sokrateen ja Platonin ja arvot ovat vaihtaneet paikkaa välineiden kanssa tai välineistä on tullut arvoja. Ihmisestä on tullut innokas väline hänelle vieraiden päämäärien toteuttamiseksi. Instrumentalismi tasoittaa niin toden ja värän kuin kauniin ja ruman ynnä muiden tällaisten vanhojen parien eroja.

Suomalaista kulttuurikeskustelua hallitsevat 2020-luvun alussa(kin) nominalismi, relativismi, pragmatismi, instrumentalismi, individualismi ja 
neoliberalismi - sen sijaan klassiset hyveet ovat kadonneet keskustelusta. Joku saattaa vielä muistaa sanonnan "rikos ei kannata". Lausumaa ei suinkaan ole tarkoitettu totuudeksi vaan mielipiteeksi, dialektiseksi eli retoriseksi argumentiksi. Vahvempi perustelu lienee se, että "kyllä rikos kannattaa." Rikos tai "rikos" todella maksaa vaivan tieteessä, taiteessa, uskonnossa, talouselämässä, politiikassa, urheilussa ja missä tahansa. Harmillisesta kiinnijäämisestä tuskin seuraa kummempia sanktioita, kuten voittoisan Laura Huhtasaaren tapaus osoittaa. Onneksi olkoon! Väärennys (väärentäminen) toki edelleen kuuluu rikoslain piiriin. Ratkaisevaa asiassa on kuitenkin vain se, haittaako väärennös vaihdantaelämän tarpeita (rahan liikettä) ja uhkaako se julkista luottamusta elämänmenon suhteelliseen rehellisyyteen vai ei ja vielä sekin, vahingoittaako se oikeussubjektia eli -alamaista.

Minua on alkanut hiertää epäilys, ettei julkista luottamusta ole enää olemassa. Ehkä sitä ei ole ollut mainittavasti olemassa koskaan muulloinkaan paitsi todennäköisesti sota-ajan, varsinkin Suomen talvisodan oloissa. Julkista luottamusta sopii verrata sosiologian alan kiisteltyyn kollektiiviseen omaantuntoon. Yhtä kaikki voisi esittää vahvanpuoleisen dialektisen argumentin, että julkisen luottamuksen ja kollektiivisen omantunnon asemesta ihmisiä nyt "yhdistää" julkinen ja kollektiivinen piittaamattomuus uusliberalismin merkeissä.

Kirjoitettuani yli 30 vuotta sitten opuksen historian väärennöksistä ja niiden motiiveista olen pannut merkille, että akateeminen väki on oppinut suhtautumaan huijauksiin, plagiaatteihin ja luoviin (sic) lainauksiin hyvin sallivasti. Kilpailu on kovempaa kuin ennen, eikä armoa anota eikä anneta. Verissä päin taistellaan työpaikoista, sijaisuuksista ja mehevistä (sekä pienenpienistäkin) apurahoista. Ne, jotka kenties yhä vetoavat arvo-objektivismin ikuisiin totuuksiin, ovat ajastaan jäljessä ja ikäviä moralisteja tai naiiveja idealisteja. Akateemiset huijaukset, plagiaatit ja luovat lainaukset ovat tainneet karata käsistä.

Nyqvist ja Oja ovat julkaisseet tiede- ja tietokirjojen valtaisasta massasta edukseen erottuvan kirjan. Opuksen substanssi on vahva, sanoma selvä ja tyyli oivallinen. Tekijät osoittavat vakuuttavasti, että väärennöksiä voi ja niitä pitääkin tarkastella omana kirjallisuuden osa-alueenaan. Niiden kulttuurihistoriallinen merkitys on paljon suurempi kuin meillä ja maailmalla on uskallettu ääneen tunnustaa. Eräästä oppineesta miehestä kasvoi toisten silmissä "mielipuoli"; hän kun todisteli, että jokseenkin kaikki muinaisen Kreikan ja Rooman runous oli kirjoitettu Italian renessanssin aikana.

Teinirunoilija Thomas Chatterton (1752-1770) ja James MacPherson (1736-1796) kirjoittivat monien muiden tavoin auki elävää menneisyyttä. Tohtori Samuel Johnson ihasteli anglien "Bristolian" Thomas-pojan "keskiaikaisia" luomuksia ja paheksui syvästi MacPhersonin muka Skotlannin ylämailta keräämän epiikan fragmentteja; kielen kuvallisuudessa ja romanttisen ja aidon tunteen palossa ne todella ovat korkean luokan maailmankirjallisuutta; niiden 
vaikutus on osoittautunut tavattomaksi. Nyqvistin ja Ojan luku "Onko Kalevala väärennös?" nostaa lisää tunteita pintaan: "Suomalaisen Kirjallisuuden Seuran julkaiseman Suomen kirjallisuushistorian (1999) mukaan Lönnrot ei tuntenut Ossianin lauluja [nootti], mutta tämä ei pidä paikkaansa” (146). Kirjallisilla väärennöksillä tekijät tarkoittavat

väärennöksiä, jotka kuuluvat kaunokirjallisuuden alaan tai jotka esitetään tunnettujen kaunokirjailijoiden tuotantoa tukevina dokumentteina, kuten [--] kirjailijoiden [--] kirjeinä tai päiväkirjoina. Kaunokirjalliset väärennökset ovat osa laajempaa tekstiväärennösten lajia, johon lukeutuvat [--] historiallisten dokumenttien väärennökset, journalistiset väärennnökset sekä plagiointi koulu- ja yliopistomaailmassa. (9)

Nyqvist ja Oja tekivät viisaasti rajoittuessaan kirjallisiin väärennöksiin: ne tarkoittavat ensisijaisesti taidekirjallisuutta, ja tähän genreen voidaan ehkä laskea jopa Mauri Sariolan ja mediakirjailija Anja Kaurasen ihmeelliset kontribuutiot. Vilpistä ollaan alalla kuin alalla yhtä pääsemättömissä kuin alkusynnistä - tai paremminkin alkuhyveestä, kiitos Nietzschen nerokkaan konseptuaalisen päivityksen. Nyqvist ja Oja tarkastelevat niin aitona esitettyä sepitettyä aineistoa (MacPhersonin väärentämä skottien "kansalliseepos", Chattertonin "keskiaikaiset" runot, kysymys Kalevalan autenttisuudesta), toisen nimissä kirjoitettuja tekstejä (Oscar Wilden tapaus) kuin plagiointia (Fabian Kostnerin Oneirine, Sariola, Kauranen, V. A. Koskenniemi).

Nyqvistin ja Ojan tutkimus viittaa etevästi myös alan ulkopuolelle: "vitaalit intressit" (ei suinkaan huvi) pakottavat ihmiset valheen tielle alalla kuin alalla (olkoonkin, että aina joku historian professori nousee Suomenmaassa väittämään, että väärennösten osuutta isänmaan historiassa on liioiteltu ja ettei Pähkinäsaaren rauhansopimusasiakirjaa olisikaan väärennetty venäläisten huijaamiseksi).

Mitä tulee tieteellisiin tutkimuksiin, joissa petos lienee ainakin yhtä tavallista kuin taidekirjallisuudessa, lienee syytä painokkaasti huomauttaa, että niissä tekijän on tapana visusti vaieta käyttämästään yhdestä ja keskeisestä lähteestä - ja menetellä muutoin aivan korrektisti. Näinkin tuotetaan pro graduja sekä ansiokkaita doktoraalisia ja postdoktoraalisia tutkielmia. Niistä tuskin jää kiinni; riski on niin pieni, että moni sen ottaa. Tarkastajilla ei ole aikaa, voimia, rahaa eikä intressejä paneutua yhtä perusteellisesti töihin kuin niiden tekijöillä, ja joissakin tapauksissa "tarkastajat" ovat mukana juonessa puolustamassa tai edistämässä "vitaaleja intressejä" hyvän ja pahan tuolla puolen.

Juhani Sarsila 